\title{
The relationship between regional economy and financial intermediation agglomeration from the perspective of Granger causality Empirical analysis from the Guangdong-Hong Kong-Macao Greater Bay Area (GBA)
}

\author{
Dezhi Guo ${ }^{1, \mathrm{a}}$,Kexin Zhou ${ }^{1, \mathrm{~b}}$ \\ ${ }^{1}$ Renmin University of China No. 59 Zhongguancun Street, Haidian District, Beijing, 100872, China \\ ${ }^{2}$ Zhejiang University of Technology No.288 Liuhe Road, Xihu District, Hangzhou, Zhejiang Province, 315000, China
}

\begin{abstract}
This paper uses the time series data from 2007 to 2017 to analyze the financial intermediation agglomeration of Guangdong-Hong Kong-Marco Greater Bay Area through the empirical method of Granger causality test to find the relationship between regional economic growth. The empirical results show that the financial intermediation in the GBA has a prominent clustering effect, which has a strong pulling effect on the regional economic growth of the GBA. However, the development of the real economy in the GBA has not played a substantial role in supporting the development of the financial intermediation.
\end{abstract}

\section{Introduction}

Levine (1998) [1], Tadesse (2002) [2], Shin (2008) [3] empirically analyze the layout data of the financial intermediation agglomeration in their respective countries, and believe that the financial intermediation agglomeration is not only conducive to the prosperity of the financial market, but also very conducive to the continued growth of the regional economy. Jianjun $\mathrm{Su}$ (2015) [4] uses the generalized least squares method of empirical methods to measure the provincial-level economic and financial related data indicators of mainland China from 1995 to 2011, and the results show that the financial intermediation agglomeration and market integration have produced regional economic growth. Synergy, and the degree of promotion of financial intermediation agglomeration to regional economic growth will increase with the increase of market integration.

The GDP of the Guangdong, Hong Kong and Macao Greater Bay Area in 2017 was 1,096.4 billion-yuan, accounting for $16 \%$ of the national (including Hong Kong and Macao) value added of financial intermediation, and it is a national regional financial center. Compared with the 2017 GDP data of various countries and regions in the world, the value added of the financial intermediation in the GBA exceeded the 57th-ranked GDP of Kazakhstan. In the 24th "GFCI" ranking, Hong Kong ranked third, Shenzhen ranked 12th, and Guangzhou ranked 19th. The GBA has excellent objective conditions, good economic growth conditions, and a reasonable industrial structure, which has laid the foundation for the concentration of the financial intermediation.

\section{Methodology}

\subsection{Financial Intermediation Location Entropy}

Location entropy measurement (LQ) can be used to measure the degree of industrial agglomeration. By measuring this indicator, you can find industries with agglomeration advantages within the region and measure their specialization rate. The formula is:

$$
L Q_{i j}=\frac{q_{i j} / q_{j}}{q_{i} / q}
$$

$\mathrm{LQ}_{\mathrm{ij}}$ is the location entropy of the financial intermediation in the GBA, $\mathrm{q}_{\mathrm{ij}}$ is the value added of financial intermediation in the GBA, and $\mathrm{q}_{\mathrm{j}}$ is the GDP of the GBA; $q_{i}$ is the value added of financial intermediation across the country (including Hong Kong and Macao), q is the national GDP (including Hong Kong and Macao). The data comes from the "China Statistical Yearbook", "Guangdong Statistical Yearbook", "Hong Kong Statistical Yearbook" and "Macao Statistical Yearbook" over the years, and the three currencies are converted according to the average exchange rate of the year. When $\mathrm{LQ}_{\mathrm{ij}}>1$, the industrial agglomeration degree of the $\mathrm{i}$ intermediation in the $j$ area is higher than the national level (or within a certain area), there is an industrial agglomeration situation, the higher the value, the higher the regional industrial agglomeration level; when $L Q_{\mathrm{ij}}<1$ The industrial agglomeration degree of intermediation $\mathrm{i}$ in area $\mathrm{j}$ is lower than the national level (or within a certain 
region), and there is often no industrial agglomeration.

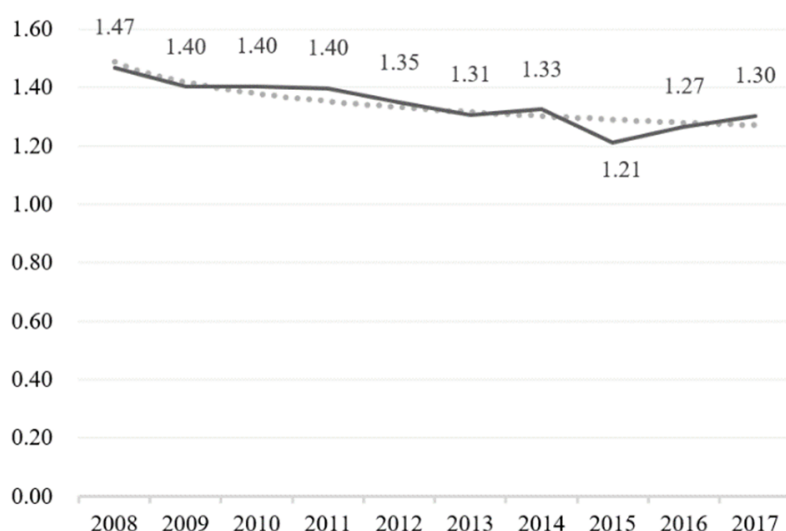

Fig1. The Line Chart of 2008-2017 GBA Financial Intermediation Location Entropy

During the ten years from 2008 to 2017 , the location entropy of the financial intermediation in the GBA was at a level greater than 1.00, and the average value was around 1.38. The development trend was U-shaped, indicating the development of the financial intermediation in the GBA and the level is higher than that of the whole country (including Hong Kong and Macao) and it has comparative advantages. It also shows that the financial intermediation in the GBA has a trend of agglomeration, and a certain concentration of the financial intermediation has occurred.

The location entropy of the GBA financial intermediation showed a downward trend from 2010 to 2015, mainly because the global financial crisis that broke out in 2008 had a certain negative impact on the development of the GBA financial intermediation in the next one or two years.

After 2010, Shenzhen and other manufacturing cities deepened industrial transformation and reform, accelerated the elimination of low-end enterprises, and increased support and development of emerging industries. The secondary industry of Shenzhen increased its contribution to GDP, while lower-end manufacturing industries and the migration of internal cities increases the proportion of secondary industries in GDP in the internal cities. Under the overall effect, the proportion of secondary industries in GDP in the GBA increases, so the location entropy of the financial intermediation in the GBA also declined in 2010-2015.

In 2015, there were many events that favored the financial market environment and confidence, such as RMB joining the SDR, the establishment of the Asian Investment Bank, etc., and the emerging industries in the GBA that are becoming more mature and need financial market support, so the GBA financial intermediation is more active. The GBA financial location entropy gradually increased.

\section{Empirical analysis}

\subsection{Data index selection and model formulation}

According to the relevance and collectability of the data, the GDP (X) of GBA, the per capita GDP (Y) of GBA, and the imports and exports $(\mathrm{Z})$ of GBA were selected as the explanatory variables. The value added of financial intermediation in the GBA (A), the deposits and loans amount of the local and foreign currencies of financial institutions in the GBA (B), and the location entropy of the financial intermediation in the GBA (C) are explanatory variables. Because these six variables are regional economic indicators and are susceptible to fluctuations in domestic and foreign macroeconomic forms, the six variables are logarithmically processed to obtain a new set of variables: $\operatorname{Ln} A, \operatorname{Ln} B$, Ln C, Ln X, Ln Y, Ln Z, The 2007-2017 macroeconomic data of Mainland China, Guangdong Province, Hong Kong and Macau Special Administrative Regions were used as the basic data of this study. The data come from the "China Statistical Yearbook", "Guangdong Statistical Yearbook", "Hong Kong Statistical Yearbook" and "Macao Statistics" "Yearbook", and according to the average exchange rate of the year, the three currencies are converted and unified. This paper uses Granger causality test model to verify the causality of variables.

\subsection{Units root test}

In order to avoid the phenomenon of "pseudo-regression" in the model, before the Granger causality test, it is necessary to determine whether the time variable sequence contains unit roots. This paper selects the ADF unit root test method proposed by Dick and Fowler, and uses Eviews10 software to test the six logarithmically processed variables.

Table1. Adf test results of six variables after digitization

\begin{tabular}{|c|c|c|c|c|c|c|}
\hline \multirow{2}{*}{ Variable } & \multirow{2}{*}{$\begin{array}{c}\text { Inspection } \\
\text { method }\end{array}$} & \multirow{2}{*}{$\begin{array}{c}\text { Meas } \\
\text { urem } \\
\text { ents }\end{array}$} & \multicolumn{3}{|c|}{ Critical value } & \multirow{2}{*}{$\begin{array}{c}\text { Critical } \\
\text { result }\end{array}$} \\
\hline & & & $1 \%$ & $5 \%$ & $10 \%$ & \\
\hline$\triangle(\operatorname{Ln} A)$ & $(\mathrm{c}, 0, \mathrm{p})$ & -6.88 & -4.42 & -3.26 & -2.77 & smooth \\
\hline$\triangle(\operatorname{Ln} B)$ & $(\mathrm{c}, 0, \mathrm{p})$ & -3.75 & -4.58 & -3.32 & -2.80 & smooth \\
\hline$\triangle(\operatorname{Ln} C)$ & $(\mathrm{c}, 0, \mathrm{p})$ & -3.57 & -4.42 & -3.26 & -2.77 & smooth \\
\hline$\triangle(\operatorname{Ln} X)$ & $(\mathrm{c}, \mathrm{t}, \mathrm{p})$ & -5.99 & -5.84 & -4.25 & -3.59 & smooth \\
\hline$\triangle(\operatorname{Ln} Y)$ & $(\mathrm{c}, \mathrm{t}, \mathrm{p})$ & -5.55 & -5.84 & -4.25 & -3.59 & smooth \\
\hline$\triangle(\operatorname{Ln} Z)$ & $(\mathrm{c}, \mathrm{t}, \mathrm{p})$ & -5.59 & -5.84 & -4.25 & -3.59 & smooth \\
\hline
\end{tabular}

The original sequences of the variables $\operatorname{Ln} A, \operatorname{Ln} B, \operatorname{Ln}$ C, Ln X, Ln Y, Ln Z are not stable, but the first-order difference sequence is stable, the ADF test value is below the critical value level of $5 \%$, and the $P$ value is significant, you can reject the existence of unit roots The null hypothesis is that the six variables all have the same cointegration order and are first-order single-integer sequences.

\subsection{Cointegration test}

The GDP (X), GDP per capita (Y), and imports and export $s$ trade volume $(\mathrm{Z})$ of the GBA are the explanatory variables. A), the deposits and loans amount of the local and foreign currencies of financial institutions (B), the financial intermediation location entropy (C) are explanatory variables, and the regression results between the variables are as follows: 
Ln $X=1.856-0.017 \mathrm{LnA}+0.754 \mathrm{LnB}-0.095 \mathrm{LnC}$

$\mathrm{R} 2=0.992 \quad \log \mathrm{L}=25.316 \quad$ F-statistic $=301.396$

$\mathrm{AIC}=-3.876$

Ln $\mathrm{Y}=-4.046+0.358 \mathrm{LnA}+0.264 \mathrm{LnB}-0.189 \mathrm{LnC}$ (2)

$\mathrm{R} 2=0.988 \quad \log \mathrm{L}=25.253 \quad$ F-statistic $=191.761$

$\mathrm{AIC}=-3.864$

$\operatorname{Ln} \mathrm{Z}=6.313+0.013 \mathrm{LnA}+0.405 \mathrm{LnB}+0.501 \mathrm{LnC}$ (3)

$\mathrm{R} 2=0.788 \quad \log \mathrm{L}=15.118 \quad$ F-statistic $=8.699$

$\mathrm{AIC}=-2.021$

Table2. Adf test results of three groups of ols equation regression residuals

\begin{tabular}{|c|c|c|c|c|c|c|}
\hline \multirow[b]{2}{*}{ Variable } & \multirow{2}{*}{$\begin{array}{l}\text { Inspection } \\
\text { method }\end{array}$} & \multirow{2}{*}{$\begin{array}{l}\text { Meas } \\
\text { urem } \\
\text { ents }\end{array}$} & \multicolumn{3}{|c|}{ Critical value } & \multirow{2}{*}{$\begin{array}{c}\text { Critical } \\
\text { result }\end{array}$} \\
\hline & & & $1 \%$ & $5 \%$ & $10 \%$ & \\
\hline $\begin{array}{c}\triangle \mathrm{OLS} \\
\operatorname{Ln} \mathrm{X}\end{array}$ & $(\mathrm{c}, \mathrm{t}, \mathrm{p})$ & -4.90 & -5.84 & -4.25 & -3.59 & smooth \\
\hline $\begin{array}{c}\triangle \mathrm{OLS} \\
\mathrm{Ln} \mathrm{Y}\end{array}$ & $(\mathrm{c}, 0, \mathrm{p})$ & -3.46 & -4.42 & -3.26 & -2.77 & smooth \\
\hline $\begin{array}{c}\triangle \mathrm{OLS} \\
\mathrm{Ln} Z\end{array}$ & $(\mathrm{c}, \mathrm{t}, \mathrm{p})$ & -5.34 & -5.84 & -4.25 & -3.59 & smooth \\
\hline
\end{tabular}

The first-order difference sequences of the regression residuals of the three groups of OLS equations are all stationary. The ADF test value is lower than the critical value level of $5 \%$, and the $\mathrm{P}$ value is significant. The explained variable has a long-term stable equilibrium relationship. Since the co-integration relationship can only show that there is a mutual relationship between the variables, it cannot explain which variable is the cause and which variable is the result. It is necessary to further examine the causal direction of the six variables.

\subsection{Granger causality test}

When there is a long-term equilibrium relationship between two variables, there is at least one Granger causality in one direction, and whether there is a causal relationship between variables and the direction of the causal relationship can be Judgment by Granger causality test.

Table3. Granger test results

\begin{tabular}{|c|c|c|c|}
\hline Null hypothesis & F value & P value & Test result \\
\hline $\begin{array}{c}\text { Granger reason why } \\
\text { Ln A is not Ln X }\end{array}$ & 5.04502 & $0.0806^{*}$ & $\begin{array}{c}\text { Reject the null } \\
\text { hypothesis }\end{array}$ \\
\hline $\begin{array}{c}\text { Granger reason why } \\
\text { Ln X is not Ln A }\end{array}$ & 2.76783 & 0.176 & $\begin{array}{c}\text { Accept the null } \\
\text { hypothesis }\end{array}$ \\
\hline $\begin{array}{c}\text { Granger reason why } \\
\text { Ln A is not Ln Y }\end{array}$ & 6.44416 & $0.0561^{*}$ & $\begin{array}{c}\text { Reject the null } \\
\text { hypothesis }\end{array}$ \\
\hline $\begin{array}{c}\text { Granger reason why } \\
\text { Ln Y is not Ln A }\end{array}$ & 6.5161 & $0.0552^{*}$ & $\begin{array}{c}\text { Reject the null } \\
\text { hypothesis }\end{array}$ \\
\hline $\begin{array}{c}\text { Granger reason why } \\
\text { Ln A is not Ln Z }\end{array}$ & 6.85103 & $0.0511^{*}$ & $\begin{array}{c}\text { Reject the null } \\
\text { hypothesis }\end{array}$ \\
\hline $\begin{array}{c}\text { Granger reason why } \\
\text { Ln Z is not Ln A }\end{array}$ & 0.69817 & 0.5494 & $\begin{array}{c}\text { Accept the null } \\
\text { hypothesis }\end{array}$ \\
\hline $\begin{array}{c}\text { Granger reason why } \\
\text { Ln B is not Ln X }\end{array}$ & 24.1226 & $0.0059^{* * *}$ & $\begin{array}{c}\text { Reject the null } \\
\text { hypothesis }\end{array}$ \\
\hline $\begin{array}{c}\text { Granger reason why } \\
\text { Ln X is not Ln B }\end{array}$ & 2.86301 & 0.1691 & $\begin{array}{c}\text { Accept the null } \\
\text { hypothesis }\end{array}$ \\
\hline $\begin{array}{c}\text { Granger reason why } \\
\text { Ln B is not Ln Y }\end{array}$ & 14.8398 & $0.0141 * *$ & $\begin{array}{c}\text { Reject the null } \\
\text { hypothesis }\end{array}$ \\
\hline $\begin{array}{c}\text { Granger reason why } \\
\text { Ln Y is not Ln B }\end{array}$ & 3.3129 & 0.1417 & $\begin{array}{c}\text { Accept the null } \\
\text { hypothesis }\end{array}$ \\
\hline $\begin{array}{c}\text { Granger reason why } \\
\text { Ln B is not Ln Z }\end{array}$ & 9.61784 & $0.0296^{* *}$ & $\begin{array}{c}\text { Reject the null } \\
\text { hypothesis }\end{array}$ \\
\hline
\end{tabular}

\begin{tabular}{|c|l|l|c|}
\hline $\begin{array}{c}\text { Granger reason why } \\
\text { Ln Z is not Ln B }\end{array}$ & 2.64142 & 0.1857 & $\begin{array}{c}\text { Accept the null } \\
\text { hypothesis }\end{array}$ \\
\hline $\begin{array}{c}\text { Granger reason why } \\
\text { Ln C is not Ln X }\end{array}$ & 26.9111 & $0.0048^{* * *}$ & $\begin{array}{c}\text { Reject the null } \\
\text { hypothesis }\end{array}$ \\
\hline $\begin{array}{c}\text { Granger reason why } \\
\text { Ln X is not Ln C }\end{array}$ & 2.43992 & 0.2029 & $\begin{array}{c}\text { Accept the null } \\
\text { hypothesis }\end{array}$ \\
\hline $\begin{array}{c}\text { Granger reason why } \\
\text { Ln C is not Ln Y }\end{array}$ & 15.2176 & $0.0135^{* *}$ & $\begin{array}{c}\text { Reject the null } \\
\text { hypothesis }\end{array}$ \\
\hline $\begin{array}{c}\text { Granger reason why } \\
\text { Ln Y is not Ln C }\end{array}$ & 1.81405 & 0.275 & $\begin{array}{c}\text { Accept the null } \\
\text { hypothesis }\end{array}$ \\
\hline $\begin{array}{c}\text { Granger reason why } \\
\text { Ln C is not Ln Z }\end{array}$ & 8.26352 & $0.038^{* *}$ & $\begin{array}{c}\text { Reject the null } \\
\text { hypothesis }\end{array}$ \\
\hline $\begin{array}{c}\text { Granger reason why } \\
\text { Ln Z is not Ln C }\end{array}$ & 2.71228 & 0.1801 & $\begin{array}{c}\text { Accept the null } \\
\text { hypothesis }\end{array}$ \\
\hline
\end{tabular}

\section{Conclusion}

The growth of the deposits and loans amount of the local and foreign currencies of financial institutions is an important Granger reason for the growth of GDP, GDP per capita, and imports and exports trade volume of the GBA. The banking converts savings into investments and provides professional financial services. Development provides sufficient funds and professional service support to achieve the diffusion effect of financial agglomeration. On the other hand, the growth of the GDP, GDP per capita, and import and export trade volume of the GBA is not the Granger reason for the increase in the deposit and loan amount of local and foreign currencies. This shows that the development of the banking in the GBA is not sufficiently integrated, and a virtuous circle that is not sufficiently consolidated has not been formed

The increase in the location entropy of the financial intermediation in the GBA is an important Granger reason for the growth of GDP, GDP per capita, and imports and exports trade volume of the GBA. The support of funds on similar channels has realized the diffusion effect, which also proves that the improvement of the level of financial intermediation agglomeration will contribute to the growth of the regional economy.

The increase in the value added of the financial intermediation in the GBA is an important Granger reason for the growth of GDP, per capita GDP, and imports and exports trade volume of the GBA. The improvement of the overall development level of the financial intermediation can provide a more standardized and professional of financial services, the radiation effect is significant. Conversely, only the increase in GDP per capita will promote the increase in the output value of the financial intermediation, indicating that the economic development in the GBA that is uneven, and the industrial structure is still dominated by the primary and secondary industries, which need to be further upgraded.

\section{References}

1. Levine, R (1998). Zervos S. Stock Markets, Banks and Economic Growth [J].American Economic Review,88(3):537-558

2. Tadesse, S (2002). Financial Architecture and Economic Performance: International Evidence [J].Financial Development and Tecchnology ,11(4):429-454 
3. Buera, F and Shin, Y (2008). Financial Friction and the Persistence of History: A Quantitative Exploration [R].University of California Mimeographed Document.

4. Jianjun $\mathrm{Su}$, Jieyu Huang, Zhangyong $\mathrm{Xu}$ (2015). Financial agglomeration, domestic market integration and economic growth $[\mathrm{J}]$. Chemical Industry Technology and Economy, 108-115

5. King R G, Levine R (1993). Finance and growth: Schumpeter might be right $[\mathrm{J}]$. The quarterly journal of economics, 108(3):717-737.

6. Marshall A (1920). Principles of Economies. London: Macmillan Press [M].234-238.

7. Kindle Berger C P (1974). The Formation of Financial Centers: A Study of Comparative Economic history, Princeton: Princeton University Press, 58-70.

8. Porter M (1998). Competitive Strategy: Techniques for Analyzing Industries and Competitors. New York: Free Press, 102-150. 